\title{
Boron Improves Growth, Yield, Quality, and Nutrient Content of Tomato
}

\author{
Jeanine M. Davis, ${ }^{1}$ Douglas C. Sanders, ${ }^{2}$ Paul V. Nelson, ${ }^{2}$ Laura Lengnick, ${ }^{3}$ and Wade J. Sperry ${ }^{4}$ \\ Department of Horticultural Science, North Carolina State University, Raleigh, NC 27695-7609
}

\begin{abstract}
AdDitional INDEX wORDs. Lycopersicon esculetum, potassium, calcium, hydroponics, fruit crack, shelf life
Abstract. Boron deficiency in fresh-market tomatoes (Lycopersicon esculentum Mill.) is a widespread problem that reduces yield and fruit quality but is often not recognized by growers. Tomatoes were grown in field and hydroponic culture to compare the effects of foliar and soil applied B on plant growth, fruit yield, fruit quality, and tissue nutrient levels. Regardless of application method, $B$ was associated with increased tomato growth and the concentration of $K$, $\mathrm{Ca}$, and $\mathrm{B}$ in plant tissue. Boron application was associated with increased $\mathrm{N}$ uptake by tomato in field culture, but not under hydroponic culture. In field culture, foliar and/or soil applied B similarly increased fresh-market tomato plant and root dry weight, uptake, and tissue concentrations of $\mathrm{N}, \mathrm{Ca}, \mathrm{K}$, and $\mathrm{B}$, and improved fruit set, total yields, marketable yields, fruit shelf life, and fruit firmness. The similar growth and yield responses of tomato to foliar and root $B$ application suggests that $B$ is translocated in the phloem in tomatoes. Fruit from plants receiving foliar or root applied $B$ contained more $B$, and $K$ than fruit from plants not receiving $B$, indicating that $B$ was translocated from leaves to fruit and is an important factor in the management of $\mathrm{K}$ nutrition in tomato.
\end{abstract}

Boron deficiency in fresh-market tomatoes (Lycopersicon esculentum Mill.) is often not recognized by growers. Boron deficiency, however, is widespread (Gupta et al., 1985) and can cause serious yield reductions and uneven ripening of tomato fruit (Adams, 1978). Boron becomes less available to plants as soil $\mathrm{pH}$ increases (Bunt, 1956). Therefore the practice of applying lime to improve the uptake of other important nutrients can cause B deficiency (Fleming, 1980). Boron deficiency can also occur readily in tomatoes grown in areas with acid sandy soils and heavy rainfall (Adams, 1986) because it is easily leached under such conditions (Mengel and Kirkby, 1987). These conditions are common in the southeastern United States (Mortvedt and Woodruff, 1993; Offiah and Axley, 1993) and increase the difficulty of managing B nutrition in tomatoes in this region.

Maintenance of high foliage K levels during tomato fruit development is recommended but is often difficult to achieve (Adams, 1986; Bradley and Flemming, 1960). Fruit become large sinks for $\mathrm{K}$ as they develop, thereby diminishing $\mathrm{K}$ levels in leaves that are needed for continued plant growth and physiological processes (Ho and Hewitt, 1986). Adequate B levels help to maintain leaf $\mathrm{K}$ levels in tomato during fruit development (Sperry, 1995). Blevins et al. (1993) reported that B has a major influence on the plasma membrane of plant cells and ion transport and that $\mathrm{B}$ amendments increased $\mathrm{K}, \mathrm{Ca}$, and $\mathrm{Mg}$ levels in soybean [Glycine $\max (\mathrm{L}$.$) Merr.] leaves.$

Fresh-market tomato production commonly involves use of raised beds with black polyethylene mulch and drip-irrigation. Soluble fertilizers are often applied directly to the root zone through the drip-irrigation system. Although B can be supplied to tomatoes as dry fertilizer (Mortvedt and Woodruff, 1993), dry B formulations are difficult to manage because typically very small amounts are required, it is subject to loss by leaching, and the range of deficient to toxic levels of soil B is very narrow (Reisenauer et al., 1973).

Application of B to tomatoes via drip-irrigation or in a regular

Received for publication 1 July 2002. Accepted for publication 14 Jan. 2003. ${ }^{1}$ Associate professor, Mountain Horticultural Crops Research and Extension Center, 455 Research Drive, Fletcher, NC 28732.

2Professor.

${ }^{3}$ Consultant.

${ }^{4}$ Former graduate research assistant. foliar spray regime ensures a steady supply of B throughout the growing season without the management concerns of supplying $\mathrm{B}$ as a dry formulation. Application through the drip-irrigation system places B directly in the root zone and foliar B applications allow uptake directly through the leaves. The objective of this study was to determine if $\mathrm{B}$, applied in a liquid formulation to the foliage and/or roots, would improve yields, fruit quality, and nutrient content of tomatoes.

\section{Materials and Methods}

Hydroponic STUdiEs. Production of tomato seedlings for the hydroponic study was carried out by seeding fresh-market ' $\mathrm{Ce}$ lebrity' tomato in flats containing steam sterilized river bottom sand. Flats were placed in a deionized water intermittent mist bed under cycles of $23{ }^{\circ} \mathrm{C}$ day $/ 18{ }^{\circ} \mathrm{C}$ night with an 18 -h photoperiod provided by cool-white fluorescent lamps. Eighteen days following sowing, seedlings were transplanted to acid washed 3.75-L plastic containers containing continuously aerated nutrient solutions and placed in a greenhouse. To eliminate light, the plastic containers were sprayed with aluminum colored paint and polystyrene covers were made to fit tightly in the openings. Three small holes were bored in each cover to accommodate two plants (one plant per hole) and an air tube. A closed-circle air manifold was constructed with Tygon tubing and attached to an air pump (Rev-A, Thomas Industries, Inc., Pittsburgh, Pa.) and acid washed air stones were attached to the manifold, placed in the containers, and suspended $2.5 \mathrm{~cm}$ from the bottom of the container. Constant levels of a modified Hoagland solution minus the B (Maynard and Hochmuth, 1997) were maintained in the plastic containers by adding double-deionized water daily. Nutrient solutions were completely changed every $7 \mathrm{~d}$.

Three treatments were applied in this study: no B; $1 \mathrm{mg} \cdot \mathrm{L}^{-1} \mathrm{~B}$ as $\mathrm{H}_{3} \mathrm{BO}_{3}$ supplied in the nutrient solution; and a foliar application of $1.87 \mathrm{mg} \cdot \mathrm{L}^{-1} \mathrm{~B}$ as N-Boron (4.5-0-0 with $3.3 \% \mathrm{~B}$ chelated with mannitol) (Claw El, Divison of Brandt Consolidated, Pleasant Plains, Ill.) Treatments were started when seedlings were placed in the $3.75-\mathrm{L}$ containers. The B treatments were supplied continuously in the nutrient solution and the foliar applications were applied every seven days. The foliar treatments were applied with a hand held spray bottle and sprayed until just before run off. To 
prevent contamination of plant roots and growth solution with the foliar spray treatment, containers were taken to a separate room before treatment and the containers and plants up to the first leaves were protected by securing a 56.7-L plastic bag tightly around the stem. A new bag was used for each container and each time a treatment was applied. Plants were harvested $56 \mathrm{~d}$ after transplanting. To remove B treatment surface residues from roots and shoots, the tissues were rinsed under warm tap water for $15 \mathrm{~s}$, washed for $30 \mathrm{~s}$ in $0.2 \mathrm{~N} \mathrm{HCl}$, rinsed under warm tap water for $15 \mathrm{~s}$, and rinsed for $30 \mathrm{~s}$ in distilled water (Williams and Nelson, 1992). All samples were weighed, dried at $70{ }^{\circ} \mathrm{C}$ for 72 $\mathrm{h}$, reweighed, ground in a stainless steel Wiley mill) to a particle size $\leq 1 \mathrm{~mm}\left(20\right.$-mesh screen), and dry-ashed at $500^{\circ} \mathrm{C}$. Samples were analyzed for total $\mathrm{N}$ by a semimicro-Kheldahl procedure in which salicylic acid was added as a pretreatment to digestion to aid in the reduction of $\mathrm{NO}_{3}$ (Eastin, 1978). Boron was determined by the curcumin procedure (Grinstead and Snider, 1967) and $\mathrm{K}, \mathrm{Ca}, \mathrm{Mg}$, and $\mathrm{S}$ (sulfur) were analyzed by atomic absorption spectroscopy (Christian and Feldman, 1970). Phosphorus was analyzed colorometrically (Chapman and Pratt, 1961) using a UV/VIS spectrophotometer (Perkin-Elmer, Norwalk, Conn.). An estimate of total nutrient uptake was calculated by multiplying the concentration of nutrient (mg nutrient/g plant tissue) by the total dry weight of the specific plant tissue.

This study was repeated three times using a randomized complete block design with three treatments and five replications. A fourth study was conducted that included the three treatments described previously, plus an additional foliar + root B application treatment. The foliar+root B application treatment supplied 1 $\mathrm{mg} \cdot \mathrm{L}^{-1} \mathrm{~B}$ from $\mathrm{H}_{3} \mathrm{BO}_{3}$ in the nutrient solution and $1.87 \mathrm{mg} \cdot \mathrm{L}^{-1} \mathrm{~B}$ as an N-Boron foliar spray. Except for the addition of the foliar+root $\mathrm{B}$ application treatment, the fourth study was conducted using the same materials and methods as described previously.

The results of all four experiments were subjected to ANOVA. No treatment by experiment interactions were found, so the data were grouped as one experiment with four treatments and unequal replication $(\mathrm{n}=5$ for the foliar + root treatment, $\mathrm{n}=20$ for all other treatments). The grouped data were subjected to analysis of variance and, where appropriate, to the F protected LSD mean separation test using SAS (SAS Institute, Cary, N.C.).

FIELD STUDY. This field study was conducted on a Norfolk loamy sand (fine loamy, siliceous, thermic Typic Paleudult) in Clayton, N.C. Soil had a pH of 6.6 and contained less than $0.1 \mathrm{mg} \cdot \mathrm{kg}^{-1} \mathrm{~B}$. This site was selected because B deficiency symptoms are likely to occur in tomato plants when soil B concentrations are below a critical level of 0.1-0.7 mg. $\mathrm{kg}^{-1}$ (Maynard and Hochmuth, 1997). Soil B levels were analyzed colorometrically using the hot-watersoluble B extraction method of McGeehan et al. (1989).

The experimental site was prepared for tomato production by the application of $11.2 \mathrm{~kg} \cdot \mathrm{ha}^{-1} \mathrm{P}, 84 \mathrm{~kg} \cdot \mathrm{ha}^{-1} \mathrm{~K}$, and $56 \mathrm{~kg} \cdot \mathrm{ha}^{-1}$ $\mathrm{N}$ broadcast applied and incorporated into the soil. Beds were formed and fumigated with a mixture of $67 \%$ methylbromide and $33 \%$ chloropicrin $\left(\mathrm{CCl}_{3} \mathrm{NO}_{2}\right)$ at $224 \mathrm{~kg} \cdot \mathrm{ha}^{-1} 4$ weeks before planting. At the same time, black polyethylene mulch $(1.5 \mathrm{~m}$ wide $\times 0.04 \mathrm{~mm}$ thick) and drip-tape $(61 \mathrm{~cm}$ emitter spacing) (Typhoon: Netafim, Valley Stream, N.Y.) were applied. The drip-tape was placed $4 \mathrm{~cm}$ deep and $10 \mathrm{~cm}$ from the center of the bed. Plots consisted of four $4.6 \mathrm{~m}$ long rows spaced $1.5 \mathrm{~m}$ apart with the outer two rows serving as guard rows. Six-weekold greenhouse-grown 'Celebrity' transplants were mechanically set $46 \mathrm{~cm}$ apart in-row on 3 May 1994. Plants were staked and trained to the string weave system (Konsler and Gardner, 1990).
Lateral shoots, 5 to $10 \mathrm{~cm}$ long, were removed from the base of the plant up to, but not including, the shoot immediately below the first flower cluster. Recommended weed, disease, and insect management practices (North Carolina State Univ., 1993) were used throughout the course of the study.

Treatments were assigned to the experimental plots as a randomized complete block design with three treatments and five replications. The three treatments consisted of no B fertilization, a weekly foliar B application, and a weekly soil B application. Foliar B was applied at $0.56 \mathrm{~kg} \cdot \mathrm{ha}^{-1} \mathrm{~B}$ as N-Boron using a backpack sprayer. Weekly soil B was applied at $0.56 \mathrm{~kg} \cdot \mathrm{ha}^{-1}$ through a line of drip-tape separate from the irrigation drip-tape, placed directly under the polyethylene mulch and on top of the soil. The separate line could be attached or unattached to the irrigation driptape system when soil B treatments were applied. A polyvinyl chloride pipe injection manifold with a backflow prevention valve was constructed (Lancaster et al., 1998), connected to the soil B treatment drip system, and used to apply the soil B treatments. Application of the experimental treatments began at first anthesis and continued for 8 weeks for a total of $4.48 \mathrm{~kg} \cdot \mathrm{ha}^{-1} \mathrm{~B}$. Leaflet samples were taken from the petiole of the fourth leaf from the growing tip to evaluate $\mathrm{B}$ effects on leaflet $\mathrm{K}$ and other nutrient changes from first anthesis through fruit development. Leaflets were sampled $7 \mathrm{~d}$ following the first B applications and weekly thereafter for 8 weeks. Percent fruit set was evaluated by tagging newly opened blossoms once a week and counting the number of tagged blossoms which set fruit 1 week later. Plant height was measured from mulch surface to the growing tip at time of last harvest. Fruit were harvested six times at the breaker stage (just showing pink at the blossom end), graded, and weighed weekly. Fruit were graded into U.S. Combination, U.S. no. 3, and culls (U.S. Dept. of Agriculture, 1961). Yields reported are marketable fruit (U.S. Combination and U.S. no. 3) or total yield (marketable plus culls). Fruit were culled for cracks, zippers, cat-facing, and other damage. All cracked fruit were weighed.

Forty randomly selected fruit per plot were placed on tables in a well ventilated laboratory at $22{ }^{\circ} \mathrm{C}$ and evaluated for shelf life. Fruit were placed on paper and arranged so they were not touching. Fruit were checked daily and removed at first sign of breakdown due to dehydration or disease and days to removal were recorded.

Another randomly selected group of fruit was used for nutrient analysis. Boron treatment surface residues were removed from this fruit using the method of Williams and Nelson (1992) described previously. Fruit were cut and separated into $600 \mathrm{~g}$ allotments per plot, then dried at $70{ }^{\circ} \mathrm{C}$ for $96 \mathrm{~h}$, weighed for dry matter, ground, and analyzed for tissue nutrient content as described previously.

An additional group of randomly selected fruit was harvested from each plot at the breaker stage for crack-point testing. Forty fruit per plot were placed on paper, and arranged so they were not touching, on tables in a well-ventilated laboratory with day/ night cycles of $\approx 12 \mathrm{~h}$ at 22 to $23{ }^{\circ} \mathrm{C}$. The fruit were allowed to attain uniform ripeness of the light red stage and then subjected to crack point testing using an Instron Universal Tester (model TM; Instron Corp., Atlanta, Ga.). Pressure was exerted midway between the blossom and stem ends of the fruit with a $10.16 \mathrm{~cm}^{2}$ plate moving at constant speed. The force needed to cause the skin to crack was recorded.

Following final harvest, two plants per plot were harvested and prepared for tissue analysis as described previously. Samples were analyzed for total $\mathrm{N}, \mathrm{P}, \mathrm{K}, \mathrm{B}, \mathrm{Ca}, \mathrm{Mg}$, and $\mathrm{S}$ as described 
previously. An estimate of total nutrient uptake was calculated by multiplying the concentration of nutrient (mg nutrient per $\mathrm{g}$ plant tissue) by the total dry weight of the specific plant tissue or organ.

Data were subjected to analysis of variance and, where appropriate, to the F protected LSD mean separation test using SAS (SAS Institute, Cary, N.C.).

\section{Results and Discussion}

Hydroponic studies. Plants not treated with B had lower shoot and root dry weights than plants treated with a B application (Table 1). Stunted growth in B deficient conditions has been observed in tomato and several other crops (Gupta and Cutcliffe, 1985; Nelson et al., 1977). Shoot N, Mg, and S concentrations were not affected by B treatments (data not shown); however, plants treated with root and root+foliar applied $\mathrm{B}$ had higher shoot $\mathrm{P}$, $\mathrm{K}$, and $\mathrm{Ca}$ levels than plants not treated with $\mathrm{B}$ (Table 1). Boron applied to foliage and/or roots improved uptake of N, K, Ca, and $\mathrm{B}$ into shoots, roots, and fruit (Table 2). Boron concentration was lowest in shoots of plants receiving no B (Table 1). Potassium concentrations in tomato shoots responded positively to B supplied to the roots or as a foliar amendment, which agrees with the work of Cerda and Roorda van Eysinga (1981) on tomato and Schon and Blevins (1990) on soybean.

Roots from plants not treated with B had the lowest $\mathrm{Ca}$ and B concentration (Table 1) and were stunted with blackened tips. These are classic symptoms of B deficiency (Maynard and Hochmuth, 1997). Roots from plants receiving B had none of these symptoms. Lack of B deficiency symptoms and high tissue B concentration (Table 1) and uptake (Table 2) in roots from plants that received only foliar applied B suggests that B was translocated from foliage to roots. Roots from the control plants, although clearly B deficient, still contained small amounts of B (Table 1). We analyzed seed from 'Celebrity' tomato and 20-dold 'Celebrity' seedlings and found an average of $27 \mathrm{mg} \cdot \mathrm{kg}^{-1} \mathrm{~B}$ in seed and $10 \mathrm{mg} \cdot \mathrm{kg}^{-1} \mathrm{~B}$ in seedlings.

Historically, B has been considered to be a phloem immobile element (Oertli and Richardson, 1970). One of the exceptions appears to be some plants that translocate sugar alcohols such as mannitol and sorbitol. Sugar alcohols, however, are not present in tomatoes (Brown et al., 1999). The apparent phloem transport of B that was observed in this study has been reported by other researchers working with tomatoes (Cerda and Roorda van Eysinga, 1981) as well as a variety of other crops: in B deficient broccoli (Brassica oleracea L.) (Benson et al., 1961; Shelp, 1987) and grape (Vitis vinifera) (Scott and Schrader, 1947), or following foliar applications of B on apple [Malus $\times$ sylvestris (L.) Mill. var. domestica (Borkh.) Mansf.], pear (Pyrus communis L.), prune (Prunus domestica L.), and cherry (P. avium L.), (Picchioni et al., 1995). In a study of the mobility of foliar-applied labelled ${ }^{10} \mathrm{~B}$ in peach (Prunus persica), Shu, et al. (1993) showed that B is swiftly (within $72 \mathrm{~h}$ of foliar application) re-translocated in the phloem in priority to sinks throughout the plant, regardless of the distance from the source application. These workers conclude that the commonly held view of B as a phloem immobile element may be partly due to the difficulty of using conventional non-tracer methods to observe the movement of the small amounts of B typically involved in plant growth and development.

Field study. Plant growth and yield. Tomato response to B application under field culture supported the results observed in the hydroponic experiments. Tomatoes receiving soil or foliarapplied B had better growth and were more productive compared to plants that did not receive B (Table 3). Fruit set occurred more

Table 1. Shoot and root tissue nutrient concentration and dry matter of 56-d-old 'Celebrity' tomato grown in hydroponic culture and treated with foliar, root, foliar+root, or no applied boron.

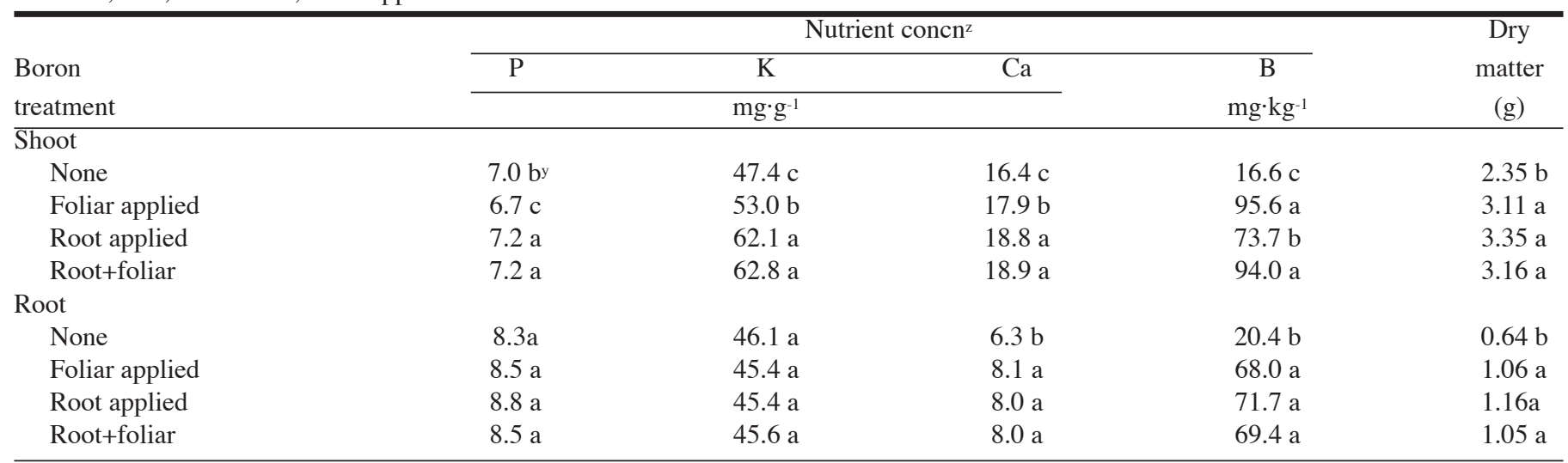

${ }^{2}$ Reported tissue concentration and dry matter means are the combined treatment means of all experiments.

yMean separation within columns by F protected LSD at $P \geq 0.05$.

Table 2. Nutrient uptake response to foliar, root, or no applied B in tomatoes under hydroponic culture.

\begin{tabular}{|c|c|c|c|c|c|c|c|c|c|c|c|c|}
\hline \multirow{3}{*}{$\begin{array}{l}\text { Boron } \\
\text { treatment }^{2}\end{array}$} & \multicolumn{4}{|c|}{ Total uptake (shoot + root) } & \multicolumn{4}{|c|}{ Shoot content } & \multicolumn{4}{|c|}{ Fruit content } \\
\hline & $\mathrm{N}$ & K & $\mathrm{Ca}$ & B & $\mathrm{N}$ & K & $\mathrm{Ca}$ & $\mathrm{B}$ & $\mathrm{N}$ & $\mathrm{K}$ & $\mathrm{Ca}$ & B \\
\hline & & $\mathrm{g} / \mathrm{plant}$ & & $\overline{\mathrm{mg} / \mathrm{plant}}$ & & $\mathrm{g} /$ plant & & $\overline{\mathrm{mg} / \mathrm{plant}}$ & & g/plant & & $\overline{\mathrm{mg} / \mathrm{plant}}$ \\
\hline None & $0.17 \mathrm{~b}^{y}$ & $0.11 \mathrm{~b}$ & $0.030 \mathrm{~b}$ & $0.03 \mathrm{~b}$ & $0.14 \mathrm{~b}$ & $0.09 \mathrm{~b}$ & $0.030 \mathrm{~b}$ & $0.02 \mathrm{c}$ & $0.03 \mathrm{~b}$ & $0.02 \mathrm{~b}$ & $0.003 \mathrm{~b}$ & $0.006 \mathrm{~b}$ \\
\hline Soil applied & $0.29 \mathrm{a}$ & $0.25 \mathrm{a}$ & $0.070 \mathrm{a}$ & $0.36 \mathrm{a}$ & $0.22 \mathrm{a}$ & $0.20 \mathrm{a}$ & $0.060 \mathrm{a}$ & $0.26 \mathrm{~b}$ & $0.07 \mathrm{a}$ & $0.05 \mathrm{a}$ & $0.008 \mathrm{a}$ & $0.090 \mathrm{a}$ \\
\hline Soil+foliar & $0.29 \mathrm{a}$ & $0.25 \mathrm{a}$ & $0.070 \mathrm{a}$ & $0.40 \mathrm{a}$ & $0.23 \mathrm{a}$ & $0.20 \mathrm{a}$ & $0.060 \mathrm{a}$ & $0.30 \mathrm{a}$ & $0.06 \mathrm{a}$ & $0.05 \mathrm{a}$ & $0.008 \mathrm{a}$ & $0.100 \mathrm{a}$ \\
\hline
\end{tabular}

${ }_{z}$ Reported nutrient uptake means are the combined treatment means of all experiments.

y Mean separation within columns by F protected LSD at $P \geq 0.05$. 
Table 3. Influence of foliar and soil applied boron on field-grown tomato quality and yield parameters.

\begin{tabular}{|c|c|c|c|c|c|c|c|c|c|c|c|c|}
\hline \multirow[b]{2}{*}{$\begin{array}{l}\text { Boron } \\
\text { treatment }\end{array}$} & \multicolumn{8}{|c|}{ Plant growth and fruit yield } & \multirow[b]{2}{*}{$\begin{array}{l}\text { Shelf } \\
\text { life } \\
\text { (d) }\end{array}$} & \multicolumn{3}{|c|}{ Fruit quality } \\
\hline & $\begin{array}{c}\text { Plant } \\
\text { dry wt } \\
(\mathrm{g})\end{array}$ & $\begin{array}{c}\text { Plant } \\
\text { ht } \\
(\mathrm{cm})\end{array}$ & $\begin{array}{c}\text { Fruit } \\
\text { set } \\
(\%)\end{array}$ & 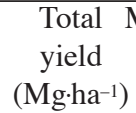 & $\begin{array}{c}\text { Marketable } \\
\text { yield } \\
(\%)\end{array}$ & Jumbo & $\frac{\text { Extra large }}{\left(\mathrm{Mg}^{2} \mathrm{ha}^{-1}\right)}$ & Large & & $\begin{array}{c}\text { Crack } \\
\text { point } \\
(\mathrm{N})\end{array}$ & $\begin{array}{l}\text { Concentric } \\
\text { crack } \\
\left(\mathrm{Mg}^{\prime} \mathrm{ha}^{-1}\right)\end{array}$ & $\begin{array}{l}\text { Radial } \\
\text { crack }\end{array}$ \\
\hline Foliar & $457 \mathrm{a}^{\mathrm{z}}$ & $135 \mathrm{a}$ & $80.4 \mathrm{a}$ & $49.6 \mathrm{a}$ & $87.5 \mathrm{a}$ & $4.69 \mathrm{a}$ & $8.96 \mathrm{a}$ & $14.4 \mathrm{a}$ & $13.0 \mathrm{a}$ & $53.2 \mathrm{a}$ & $0.78 \mathrm{~b}$ & $0.15 b$ \\
\hline Soil & $454 \mathrm{a}$ & $137 \mathrm{a}$ & $73.2 \mathrm{a}$ & $48.1 \mathrm{a}$ & $87.7 \mathrm{a}$ & $4.46 \mathrm{a}$ & $8.67 \mathrm{a}$ & $14.0 \mathrm{a}$ & $14.2 \mathrm{a}$ & $55.4 \mathrm{a}$ & $0.79 \mathrm{~b}$ & $0.26 \mathrm{ab}$ \\
\hline
\end{tabular}

zMean separation within columns by F protected LSD at $P \geq 0.05$.

Table 4. Shoot and fruit tissue nutrient concentration of fresh-market field-grown tomato treated with foliar and root applied boron.

\begin{tabular}{lccc}
\hline \multirow{2}{*}{$\begin{array}{l}\text { Boron } \\
\text { treatment }\end{array}$} & \multicolumn{3}{c}{ Nutrient concn } \\
\cline { 2 - 3 } & \multicolumn{1}{c}{$\left(\mathrm{g} \cdot \mathrm{kg}^{-1}\right)$} & $\mathrm{Ca}$ \\
\hline Shoot & $29.8 \mathrm{~b}$ & $22.9 \mathrm{~b}$ & $29.7 \mathrm{~b}$ \\
$\quad$ None & $48.7 \mathrm{a}$ & $24.8 \mathrm{ab}$ & $80.3 \mathrm{a}$ \\
$\quad$ Foliar applied & $54.8 \mathrm{a}$ & $25.1 \mathrm{a}$ & $78.2 \mathrm{a}$ \\
$\quad$ & & & \\
$\quad$ Root applied & $35.2 \mathrm{~b}$ & $2.4 \mathrm{a}$ & $17.1 \mathrm{~b}$ \\
$\quad$ Fruit & $46.9 \mathrm{a}$ & $2.6 \mathrm{a}$ & $27.3 \mathrm{a}$ \\
$\quad$ None & $44.0 \mathrm{a}$ & $2.6 \mathrm{a}$ & $28.8 \mathrm{a}$ \\
$\quad$ Foliar applied & Root applied &
\end{tabular}

${ }_{\mathrm{z}}$ Mean separation within columns by F protected LSD at $P \geq 0.05$.

than $70 \%$ of the time on plants receiving foliar or soil applied B compared to only $56 \%$ of the time on plants that did not receive $\mathrm{B}$ (Table 3). Plants receiving foliar or soil $\mathrm{B}$ had higher total and marketable yields than plants receiving no B (Table 3 ).

These results agree with other studies in which soil applied B (Gulati et al., 1980) or foliar applied B (Gascho, 1993; Oplinger et al., 1993; Schon and Blevins, 1990; Weaver et al., 1985) improved yields in tomato, soybean, and snap bean (Phaseolus vulgaris L. var. vulgaris). De Magalhaes et al. (1981) reported increased tomato fruit yields and quality with soil applied boron but had no response to foliar applied boron. Oplinger et al., (1993) observed that B applied to soybean foliage at initial flowering increased yields by $3 \%$ and Gascho (1993) reported yield increases when $\mathrm{B}$ and $\mathrm{N}$ were applied to soybean foliage during reproductive development. Yields of jumbo, extra large, and large fruit were greater when plants were treated with foliar or soil applied B than if plants received no $\mathrm{B}$ (Table 3 ). Yields of medium and small fruit were not affected by B (data not shown).

Fruit Quality. Foliar and soil applied B increased shelf life and fruit crack point compared to nontreated plants (Table 3 ). In this study, plants treated with soil applied B had a higher concentration of Ca than plants not treated with $\mathrm{B}$, but fruit Ca concentrations were not significantly different (Table 4). Similar results were obtained in a controlled environment study (Sperry, 1995).

Concentric and radial fruit crack are two common types of cracks which occur on tomatoes (Peet, 1992; Sperry, 1995). Plants treated with foliar B had less fruit with concentric and radial cracks than plants not treated with $\mathrm{B}$ (Table 3). These results suggest that B may be important in reducing the incidence of fruit cracking. Dixon et al. (1973) reported that cracking in apple was entirely eliminated by sprays containing B. This may be due to the effects of B on membranes and cell walls. Many studies have shown that B helps maintain membrane stability (Ginzburg, 1961; Pilbeam and Kirkby, 1983; Yamouchi et al., 1986). Yamouchi et al. (1986) reported that B deficiency in tomato actually induced a reduction in the amount of $\mathrm{Ca}$ associated with the pectin fraction of tomato leaf cell walls. They found $67 \%$ of the total B in the cell wall fraction of tomato leaf tissues and suggested that $\mathrm{B}$ may function in cell wall metabolism by maintaining the $\mathrm{Ca}-$ pectin association.

Tissue nutrient Content. As in the hydroponic study, K concentration (Table 4) and uptake (Table 5) were highest in shoot tissues when plants were treated with foliar or soil B. Calcium and $\mathrm{B}$ concentration (Table 4) and uptake (Table 5) were lowest in plant tissues when plants were not treated with $\mathrm{B}$, while $\mathrm{Ca}$ was highest in plants treated with soil B. This agrees with studies by Hill and Grant (1935), and Minarik and Shive (1939) who demonstrated that adding $\mathrm{B}$ to the growing medium increased the amount of $\mathrm{Ca}$ in plants. It is interesting that although total plant uptake of $\mathrm{N}, \mathrm{K}$, and $\mathrm{Ca}$ increased with $\mathrm{B}$ application (Table 5), the concentration of $\mathrm{N}$ did not (data not shown) indicating that $\mathrm{N}$ uptake keeps pace with growth while increased $\mathrm{K}$ and $\mathrm{Ca}$ uptake exceeded the increased growth resulting from B applications. Shoot N, P, Mg, and S concentrations were not altered by B treatment (data not shown).

Widders and Lorenz (1982) demonstrated that redistribution of $\mathrm{K}$ from vegetative tissues contributed up to $12 \%$ of the total $\mathrm{K}$ content of tomato fruit with subsequent foliar K levels decreasing during fruiting by $20 \%$ to $40 \%$. We wanted to observe whether soil or foliar B amendments would aid in maintenance of foliar K concentrations during fruit development. There was a significant $\mathrm{B} \times$ week interaction (Fig. 1). As fruit development progressed, leaflet $\mathrm{K}$ levels declined from $>4 \%$ to $<2 \%$ during weeks 3 through 8 in plants not treated with B. Potassium levels in plants treated with soil or foliar B declined from $\approx 4.5 \%$ at week 2 to just over $3 \%$ at week 6 and maintained these levels through week 8 . Based on these results, applied B appears to be important in maintaining high leaflet $\mathrm{K}$ concentrations in field grown tomato, especially after 5 to 6 weeks of fruit development. Similar results were found in a 2-year field study by Sperry (1995). No significant

Table 5. Total nutrient uptake response to foliar or root applied B in field-grown tomatoes.

\begin{tabular}{|c|c|c|c|c|c|c|c|c|c|c|c|c|}
\hline \multirow{2}{*}{$\begin{array}{l}\text { Boron } \\
\text { treatment }\end{array}$} & \multicolumn{4}{|c|}{ Total uptake $($ shoot + root $)\left(\mathrm{kg} \cdot \mathrm{ha}^{-1}\right)$} & \multicolumn{4}{|c|}{ Shoot uptake $\left(\mathrm{kg} \cdot \mathrm{ha}^{-1}\right)$} & \multicolumn{4}{|c|}{ Root uptake $\left(\mathrm{kg} \cdot \mathrm{ha}^{-1}\right)$} \\
\hline & $\mathrm{N}$ & K & $\mathrm{Ca}$ & B & $\mathrm{N}$ & $\mathrm{K}$ & $\mathrm{Ca}$ & B & $\mathrm{N}$ & $\mathrm{K}$ & $\mathrm{Ca}$ & B \\
\hline None & $397 b^{z}$ & $233 \mathrm{~b}$ & $137 \mathrm{~b}$ & $0.22 \mathrm{~b}$ & $329 \mathrm{~b}$ & $174 \mathrm{~b}$ & $133 \mathrm{~b}$ & $0.17 \mathrm{c}$ & $67 \mathrm{~b}$ & $60 \mathrm{~b}$ & $4.0 \mathrm{~b}$ & $0.05 \mathrm{~b}$ \\
\hline Foliar applied & $475 \mathrm{a}$ & $427 \mathrm{a}$ & $169 \mathrm{a}$ & $0.71 \mathrm{a}$ & $386 \mathrm{a}$ & $319 \mathrm{a}$ & $163 \mathrm{a}$ & $0.53 \mathrm{a}$ & $89 \mathrm{a}$ & $108 \mathrm{a}$ & $6.0 \mathrm{a}$ & $0.18 \mathrm{a}$ \\
\hline
\end{tabular}

zMean separation within columns by F protected LSD at $P \geq 0.05$. 


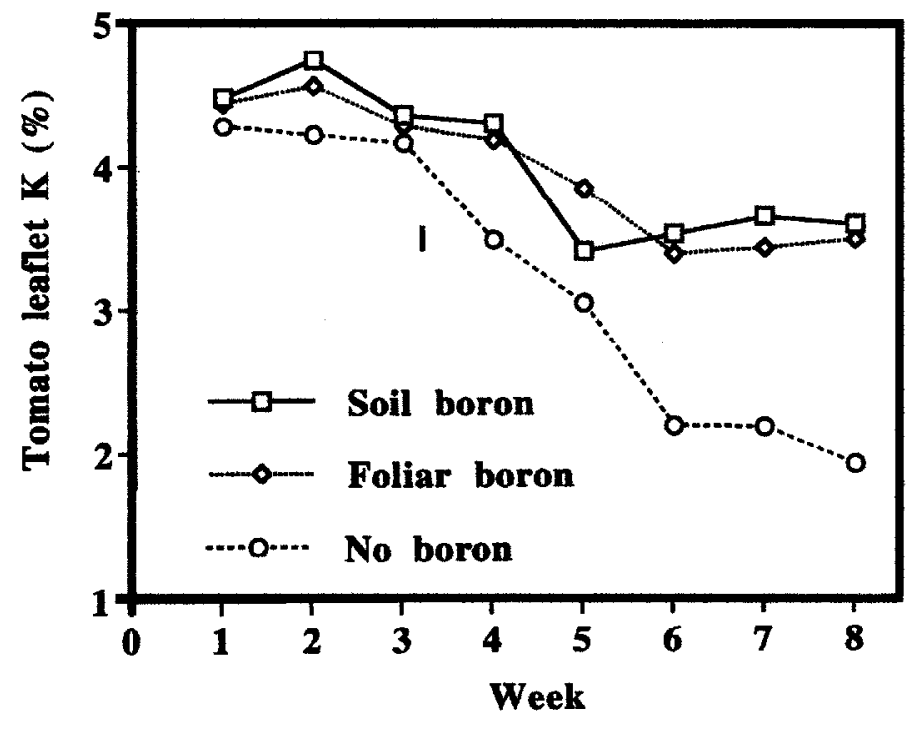

Fig. 1. Influences of foliar or soil applied B and weeks on tomato leaflet K content from field grown tomatoes. Vertical line represents LSD at $P<0.05$.

changes occurred in leaflet $\mathrm{N}, \mathrm{P}, \mathrm{Ca}, \mathrm{Mg}, \mathrm{S}$, or B levels during fruit development (data not shown).

Potassium concentration was greater in fruit from plants receiving applied B than in fruit from plants not treated with B (Table 4). This suggests that $\mathrm{B}$ is important in the maintenance of $\mathrm{K}$ levels in plant tissues including fruit and that B was transported from both roots and leaves to the developing fruit. It was shown by Sperry (1995) that foliar B sprays did not penetrate mature green tomato fruit skin. Similarly, Campbell et al. (1975) demonstrated that B moves from leaves to developing peanut (Arachis hypogaea L.) fruit and burrs of subterranean clover (Trifolium subterraneaum L.). Picchioni et al. (1995) and Hanson et al. (1985) observed that B moved out of leaves via phloem in apple, pear, plum, prune, and cherry. Boron did not influence fruit $\mathrm{N}, \mathrm{P}, \mathrm{Ca}, \mathrm{Mg}$, or $\mathrm{S}$ levels (data not shown).

\section{Conclusion}

These studies illustrate the importance of proper B nutrition to the improved production of fresh-market tomatoes. Regardless of application method, addition of B increased tomato growth; uptake of $\mathrm{N}, \mathrm{K}, \mathrm{Ca}$, and $\mathrm{B}$; and plant tissue concentrations of $\mathrm{K}$, $\mathrm{Ca}$, and B. In field culture, foliar and/or root applied B similarly increased fresh-market tomato plant and root dry weight, plant tissue concentrations and plant uptake of $\mathrm{N}, \mathrm{Ca}, \mathrm{K}$ and $\mathrm{B}$, and improved fruit set, total yields, marketable yields, fruit shelf life, and fruit firmness. The similar growth and yield responses of tomato to foliar and root B application suggests that B is translocated in the phloem in tomatoes. Fruit from plants receiving foliar or root applied B contained more B and $\mathrm{K}$ than fruit from plants not receiving $\mathrm{B}$, indicating that $\mathrm{B}$ was translocated from leaves to fruit and is an important factor in the management of $\mathrm{K}$ nutrition in tomato.

It should be noted that in the field study over $4 \mathrm{~kg} \cdot \mathrm{ha}^{-1}$ of $\mathrm{B}$ was applied per season. In the southeastern United States, B usually leaches readily from the plant root zone and B levels do not accumulate in the soil. In some soils and environments in other regions, however, high rates of $B$ applied in one season to a tomato crop may leave enough residual B in the soil to cause B toxicity if a B sensitive crop is planted in that field the following year.

\section{Literature Cited}

Adams, P. 1978. Tomatoes in peat. Part 1. How feed variations affect yield. Grower 89:1091,1093-1094.

Adams, P. 1986. Mineral nutrition, p. 281-324. In: J.G. Atherton and J. Rudich (eds.). The tomato crop. Chapman and Hall, New York.

Benson, N.R., E.S. Degman, and I.C. Chmelir. 1961. Translocation and re-use of boron in broccoli. Plant Physiol. 36:244-251.

Blevins, D.G., T.M. Reinbott, and P.J. Boyce. 1993. Foliar fertilization of soybeans with boron and magnesium: Plant physiology, p. 1-6. In: L.S. Murphy (ed.). Foliar fertilization of soybeans and cotton. PPI/FAR Tech. Bul. 1993-1, Norcross, Ga.

Bradley, E.G. and J.W. Flemming. 1960. The effects of leaf potassium and time of sampling on the relationship of leaf phosphorus and potassium to yield of cucumbers, tomatoes and watermelons. Proc. Amer. Soc. Hort. Sci. 75:617-624.

Brown, P.H., H. Hu, and W.G. Roberts. 1999. Occurrence of sugar alcohols determines boron toxicity symptoms of ornamental species. J. Amer. Soc. Hort. Sci. 124(4):347-352.

Bunt, A.C. 1956. An examination of factors contributing to the $\mathrm{pH}$ of John Innes composts. J. Hort. Sci. 31:258-271.

Campbell, L.C., M.H. Miller, and J.F. Loneragan. 1975. Translocation of boron to plant fruits. Austral. J. Physiol. 2:481-487.

Cerda, A. and J.P.N.L. Roorda van Eysinga. 1981. Growth of tomato plants in a split-root system as affected by various B levels in the nutrient solution. Neth. J. Agr. Sci. 29:199-207.

Chapman, H.D. and P.F. Pratt. 1961. Methods of analysis for soils, plants, and waters. Univ. Calif. Div. Agr. Sci., Berkley.

Christian, G.D. and F.J. Feldman. 1970. Atomic absorption spectroscopy: applications in agriculture, biology, and medicine. Wiley-Interscience, New York.

De Magalhaes, J.R. , W.L.D.E. Silva, and P.H. Monnerat. 1981. Evaluation of levels and methods of boron application in tomato. Pesquisa Agropecuaria Brasileira 16(2):153-159.

Dixon, B., G.R. Sagar, and V.M. Shorrocks. 1973. Effect of calcium and boron on the incidence of tree and storage pit in apples of the cultivar Egremont Russet. J. Hort. Sci. 48:403-411.

Eastin, E.F. 1978. Total nitrogen determination for plant material containing nitrate. Anal. Biochem. 85:591-594.

Fleming, G.A. 1980. Essential micronutrients, p. 155. In: B.E. Davies (ed.). Boron and molybdenum. Applied soil trace elements, Wiley, New York.

Gascho, G.J. 1993. Boron and nitrogen applications to soybeans: Foliar and through sprinkler irrigation, p. 17-33. In: L.S. Murphy (ed.). Foliar fertilization of soybeans and cotton, PPI/FAR Tech. Bul. 1993-1, Norcross, Ga.

Ginzburg, B.Z. 1961. Evidence for a protein gel structure cross-linked by metal cation in the intercellular cement of plant tissue. J. Expt. Bot. 12:85-107.

Grinstead, R.R. and S. Snider. 1967. Modification of the curcumin method for low level boron determination. Analyst 92:532-533.

Gulati, K.L., M.C. Oswal, and K.K. Nagpaul. 1980. Effects of concentration of boron on the uptake and yield of tomato and wheat at different levels of irrigation. Plant Soil. 54:479-483.

Gupta, U.C. and J.A. Cutcliffe. 1985. Boron nutrition of carrots and table beets grown in a boron deficient soil. Commun. Soil Sci. Plant. Anal. 16:509-511.

Gupta, V.C., Y.W. Jame, C.A. Campbell, A.J. Leyshon, and W. Nicholaichuk. 1985. Boron toxicity and deficiency: A review. Can. J. Soil Sci. 65:381-409.

Hanson, E.J., M.H. Chaplin, and P.J. Breen. 1985. Movement of foliar applied boron out of leaves and accumulation in flower buds and flower parts of 'Italian' prune. HortScience 20:747-748.

Hill, H. and E.P. Grant, 1935. The growth of turnips in artificial cultures. Sci. Agr. 15:652-659.

Ho, L.C. and J.D. Hewitt. 1986. Fruit development, p. 201-239. In: J.G. Atherton and J. Rudich (eds.). The tomato crop. Chapman and Hall, New York.

Konsler, T.K. and R.G. Gardner. 1990. Commercial production of 
staked tomatoes in North Carolina. N.C. State Univ. Agr. Ext. Serv. Publ. AG-405.

Lancaster, M.E., J.M. Davis, and D.C. Sanders. 1998. A continuously diluting injector for applying fertilizer to experimental and demonstration plots. HortTechnology 8:221-224.

Maynard, D. N. and G. J. Hochmuth. 1997. Plant growing and greenhouse vegetable production, p. 78. Knott's handbook for vegetable growers. $4^{\text {th }}$ ed. Wiley, New York.

McGeehan, S.O., K. Topper, and D.V. Naylor. 1989. Sources of variation in hot water extraction and colorimetric determination of soil boron. Commun. Soil Sci. Plant Anal. 20:1777-1780.

Mengel, K. and E.A. Kirkby. 1987. Principles of plant nutrition. $4^{\text {th }}$ ed.. Intl. Potash Inst., Worblaufen-Bern, Switzerland.

Minarik, C.E., and J.W. Shive. 1939. The effect of boron in the substrate on calcium accumulation by soybean plants. Amer. J. Bot. 26:827-831.

Mortvedt, J.J. and J.R. Woodruff. 1993. Technology and application of boron fertilizers for crops, p. 158-174. In: U.C. Gupta (ed.). Boron and its role in crop production. CRC, Boca Raton, Fla.

Nelson, P.V., D.M. Krauskopf, and N.C. Mingis. 1977. Visual symptoms of nutrient deficiencies in Rieger Elatior begonia. J. Amer. Soc. Hort. Sci. 101:65-68.

North Carolina State University. 1993. Agricultural chemicals manual. N.C. State Univ. College Agr. Life Sci., Raleigh.

Oertli, J.J. and W.F. Richardson. 1970. The mechanism of boron immobility in plants. Physiol. Plant. 23:108-116.

Offiah, O.O. and J.H. Axley. 1993. Soil testing for boron on acid soils, p. 105-123. In: U.C. Gupta (ed.). Boron and its role in crop production. CRC, Boca Raton, Fla.

Oplinger, E.S., R.G. Hoeft, J.W. Johnson, and P.W. Tracy. 1993. Boron fertilization of soybean: a regional summary, p. 7-16. In: L.S. Murphy (ed.). Foliar fertilization of soybeans and cotton, PPI/FAR Tech. Bul. 1993-1, Norcross, Ga.

Peet, M.M. 1992. Fruit cracking in tomato. HortTechnology 2: 216-223.

Picchioni, G.H., S.A. Weinbaum, and P.H. Brown. 1995. Retention and the kinetics of uptake and export of foliage-applied, labeled boron by apple, pear, prune, and sweet cherry leaves. J. Amer. Soc. Hort. Sci. 120:28-35.

Pilbeam, D.J. and E.A. Kirkby. 1983. The physiological role of boron in plants. J. Plant. Nutr. 6:563-582.

Reisenauer, H.M., L.M. Walsh, and R.G. Hoeft. 1973. Testing soils for sulfur, boron, molybdenum, and chlorine, p. 173. In: L.M. Walsh and J.D. Benton (eds.). Soil testing and plant analysis. Soil. Sci. Soc. Amer., Madison, Wis.

Schon, M.K. and D.G. Blevins. 1990. Foliar boron applications increase the final number of branches and pods on branches of field-grown soybeans. Plant Physiol. 92:602-607.

Scott, L.E. and A.L. Schrader. 1947. Effect of alternating conditions of boron nutrition upon growth and boron content of grape vines in sand culture. Plant Physiol. 22:526-537.

Shelp, B.J. 1987. The composition of phloem exudates and xylem sap from broccoli (Brassicaolearacea var. italica) supplied with $\mathrm{NH}_{4}{ }^{+}$and $\mathrm{NO}_{3}$. J. Expt. Bot. 38:1619-1624.

Shu, Z.-H., G.H. Oberly, and E.E. Carry. 1993. Time course study on the mobility and pattern of distribution of foliar-applied B in peaches. J. Plant Nutr. 16:1661-1673.

Sperry, W.J. 1995. Influence of boron and potassium on quality, yield, and nutrition of fresh-market tomato. PhD diss. N.C. State Univ., Raleigh, N.C.

U.S. Dept. of Agriculture. 1961. United States standards for grades of fresh tomatoes. USDA Agr. Mktg. Serv., Wash., D.C.

Weaver, M.L., H. Timm, H. Ng, D.W. Burke, M.J. Silbernagel, and K. Foster. 1985. Pod retention and seed yield of beans in response to chemical foliar applications. HortScience 20:429-431.

Widders, I.E. and O.A. Lorenz. 1982. Potassium nutrition during tomato plant development. J. Amer. Soc. Hort. Sci. 107:960-964.

Williams, K.A. and P.V. Nelson. 1992. Growth of chrysanthemum at low, relatively steady nutrient levels in a commercial-style substrate. HortScience 27:877-880.

Yamouchi, T., T. Hara, and Y. Sonoda. 1986. Distribution of calcium and boron in the pectin fraction of tomato leaf cell wall. Plant Cell Physiol. 27:729-732. 